\title{
The Implementation of Group Investigation Learning Model Through Domino Mathematics Media on the Rank Number and Root Form Materials
}

\author{
Cut Yuniza Eviyanti, Lia Rosita, Siti Hadijah \& Andriani \\ Department of Mathematics Education, STKIP Bumi Persada Lhokseumawe, Indonesia \\ *Corresponding author: eviyanticut@yahoo.co.id | Phone Number: +6285270410401
}

\section{ARTICLE HISTORY}

Received: 11 January 2021

Revised: 12 March 2021

Accepted: 12 April 2021

\section{KEYWORDS}

Group Investigative;

Learning model;

Domino Mathematics Media;

Rank Numbers;

Root Form;

\begin{abstract}
This study aims to find out the results of students' learning through the implementation of a group investigation learning model through mathematical domino media better than the implementation of a conventional learning model on the rank number and root form materials. The study was a quasi-experiment with the design of a randomized control group pretest-posttest. The population of this research is the entire class IX SMP Negeri 1 Lhokseumawe consisting of 9 classes. The research sample was determined by a randomized technique that made 2 classes namely experiment class (IXA) and control class (IXB). The results of the student posttest data test show that the data is distributed normally and homogeneously, so it can be analyzed with one-side t-test statistics at a significant $\alpha=0.05$. Based on the results of data processing against the posttest students obtained sig scores. (2-tailed) posttest data is 0.001 which means less than $\alpha=0.05$, this means $\mathrm{H}_{0}$ is rejected, so it can be concluded that the learning results of students taught by the group investigation learning model through domino mathematics media are better than conventional learning models on the rank number and root form materials in grade IX of SMP Negeri 1 Lhokseumawe.
\end{abstract}

\section{INTRODUCTION}

Mathematics is a science that is very closely related to daily life. Mathematics learning has a function as a means to develop critical, logical, and creative thinking skills. The process of thinking in solving mathematical problems requires intellectual ability. It will of course train students to think critically, logically, and creatively. (Siagian et al., 2019) said that "mathematics learning is an important matter to be considered to maximize student mathematics learning achievement". Currently, discussions on teaching mathematics have suggested that in the classroom must be realized through the transversality of knowledge and justified by considering mathematics as a cognitive complex in which the manifestation of human thought about investigations, understandings, and explanations of reality are substantiated (Mendes, 2019).

Rank and root form is one of the difficult materials in mathematics subjects, one of which is for students at SMP Negeri 1 Lhokseumawe. This is seen from the low replay results in the material, only 16 students out of 145 students who scored 75 and above, the rest got grades below 75 . This finding is further reinforced by the low results of the critical thinking ability test students are given during observation. None of the students managed to solve the problem completely and correctly. This can be seen from Figure 1 .

This is an open access article under the CC-BY-SA license.

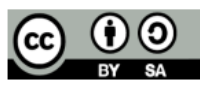

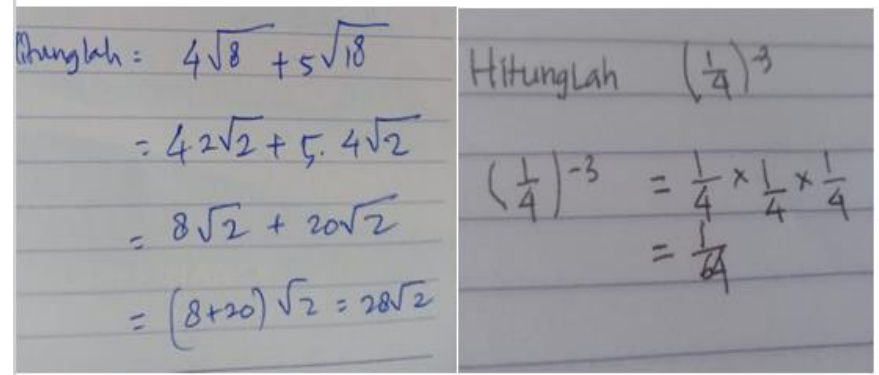

Figure 1. Some of the students' answers

The answer mentioned in Figure 1. above has a fundamental error because students do not yet understand the concept of rank numbers and root form so the student answer process has not led to the appropriate answer. This is also following research (Herawati, 2017) which explained that learning completeness is still far below average. Causes of difficulty of learners in solving problems on the material weaknesses in understanding the basic concepts of integers, weaknesses in understanding the properties of rank numbers and the root, the concept of rank number operation, is not skilled in carrying out the procedures and algorithms necessary to solve the problem. One important factor that can 
improve mathematical skills is to conduct quality learning by making the right learning materials. The use of learning materials provides good benefits in learning (Hasibuan et al., 2019).

Rank numbers and root form are essential in daily life. So mastery of rank number and root form material is very important for students, therefore understanding rank number and root form material need to be emphasized as early as possible in students. Advances in science will affect effective ways of learning, so there needs to be a directional and clear way of thinking. The model in learning is also very decisive in the achievement of good learning outcomes.

According to (Suprihatiningrum, 2013), the learning model is a carefully planned pattern and is a guideline for the implementation of learning from the opening, core, and closing and assessment of learning arranged in such a way as to achieve the purpose of learning. Several previous studies, such as (Usmadi, 2020; Samsuriadi \& Imron, 2019; Putriani \& Rahayu, 2018; Ridhollah et al, 2021; Sarah et al, 2021) found that learning models greatly affect students' ability to learn mathematics. This is in line with research (Paroqi et al, 2020; Yarmasi et al, 2020; Maulidawati et al, 2020; and Fonna \& Mursalin, 2019) that the learning process that occurs in the classroom is also strongly influenced by the model used by the teacher when conditioning students in learning mathematics. Along with the development of strategies, models, and methods of teaching teachers in learning theory where mathematics is one of the objects that receive the benefits of the new model. This is because mathematics is one of the subjects that need attention from research in the field of education.

The success of the learning process is inseparable from the ability of teachers to implement learning models oriented towards increasing the intensity of student involvement effectively in the learning process (Anggraini et al., 2010). Thus, the main consideration of the learning model is the teaching objectives that you want to achieve. According to Slavin (Rusman, 2010) said, "cooperative learning encourages students to interact actively and positively in groups". In this cooperative learning model, teachers play more of a role as facilitators. Cooperative learning is one of the constructivist-based learning models. According to Rockwood (Alzahrani, 2017) that cooperative learning was a useful means to reach mastery of fundamental knowledge, and only then would students become ready to converse, discuss, and assess.

One of the cooperative learning models of group investigation type is very precisely used for math lessons that emphasize students to investigate one concept of the topic studied. (Ahsanah, 2015) said, "Cooperative learning teaching model is one model of learning that support contextual learning". Then (Wulandari et al., 2016) said, "The group's investigative learning model emphasizes the process of actively establishing knowledge by students". Meanwhile (Sofroniou \& Poutos, 2016) said that the group work learning helped to deepen students' understanding of the material.

Group investigation is one of the cooperative learning models that give students the possibility to be able to think critically through various activities from the results of the investigation. In the activities of the Group Investigation learning model, students have already been able to solve problem-solving skills and self-confidence (Muhammad, 2018). This is in accordance with the research (Dwi Indarti \& Pramudya, 2017) said, "Based on the results of data analysis and discussion, it can be concluded that the students taught using GI learning model with scientific approach has better mathematics achievement than the students taught using a conventional learning model". (Untoro, 2016) said, the group investigation method requires the students to form small interest groups, plan and implement their investigation, synthesize the group members' findings, and make a presentation.

One of these activities is to use domino mathematics media. According to (Sri Adi Widodo, 2018), Learning media is a tool that can be used to convey the message to the students for learning can be achieved. (Nugraha \& Rafidiyah, 2019) said that "The game (domino card) can provide a diverse learning experience without eliminating the essence of the knowledge that conveyed, so the game used as a medium is unique and attracts the attention of students". The classification of teaching techniques based on the learning style can be used by teachers to develop the cognitive skills of students (Sheromova et al., 2020).

In this model teachers only act as facilitators. The group's investigative learning model can be used by teachers to improve students' critical thinking patterns, both individually and in groups. (Sumarmi, 2012) said, "Group Investigation is a cooperative learning involving small groups, students use cooperative induction (group planning and discussion) and then present their findings in class". This learning model is designed to help with the sharing of responsibilities when students follow the learning and are oriented towards the social formation. (Arinda et al., 2019) says, "the group's investigative learning model makes students more active in experimenting and exchanging ideas, in addition to making students learn in small group situations, where students are given responsibility for their own learning, as are other students of different groups".

Conventional learning is learning that teachers often use during the learning process. This learning is centered on the teacher where the teacher acts as the speaker, the information is conveyed to the student, then the teacher guides the student in the training. (Hendriana, 2017) said, "the mathematical hard skills and soft skills of the students who learn using innovative learning are better than that of students learning through conventional learning".

Based on the descriptions, opinions, and pre-research data above, the authors felt it was important to research by titled The Implementation of Group Investigation Learning Model Through Domino Mathematics Media on the Rank Number and Root Form Materials. The purpose of this research is to find out the results of students' learning through the implementation of a group investigation learning model through mathematical domino media better than the implementation of a conventional learning model on the rank number and root form materials in grade IX of SMP Negeri 1 Lhokseumawe. For students, it is expected that a varied learning experience, can increase interest and learning outcomes in the material of rank numbers and root forms.

\section{METHODS}

This study was conducted at SMP Negeri 1 Lhokseumawe (junior high school). The reason for the selection of the location of this research is because these junior high school students have good ability in terms of absorption and mastery of materials to facilitate researchers in conducting research. The population in this research is all grade IX students of SMP 
Negeri 1 Lhokseumawe which consists of 9 classes. While sampling and determining sample classes are taken randomly, i.e. taken 2 classes, one class as a control class, and one class as an experiment class. This research is a urination study experiment using the design of randomized control group pre-test- post-test research with patterns such as the design of the research in the Table 1 .

\subsection{Data Collection Techniques}

In data collection, the instruments used are pre-test and post-test. The initial test is a test conducted to know the extent of the student's initial ability before learning is applied, while the post-test is a test conducted to see the student's learning results after learning is applied. Pre-test and post-test questions in the form of essays. Researchers conducted 5 meetings, 1 pre-test, 3 studies. and 1 post-test to obtain data. Pre-test and post-test are given to all experimental and control class students. Research instruments in the form of tests on the material of rank numbers and root forms are arranged and measured in advance the level (criteria) of validity before use in data collection, to obtain the accuracy of the data. This is done to meet the theoretical validity of the instrument.

\subsection{Data Analysis Techniques}

The data analyzed in this research, obtained from tests at the end of learning (after treatment), is called the post-test. Once the post-test value is obtained, it is necessary to do a normality test and homogeneity test.

Table 1. Pre-test- post-test group control design

\begin{tabular}{cccc}
\hline Sample & Pre-test & Treatment & Post-test \\
\hline Experiment class & $X_{e}$ & $A$ & $Y_{e}$ \\
\hline Control class & $X_{k}$ & 0 & $Y_{k}$ \\
\hline
\end{tabular}

\section{Description:}

Xe : Pre-test for experiment class

$\mathrm{Xk}$ : Pre-test for control class

Ye : Post-test for experiment class

Yk : Post-test for control class

A : Treatment using the group's investigative learning model

$\mathrm{O}$ : Treatment using conventional learning

\section{RESULTS AND DISCUSSION}

The results obtained from the research conducted at SMP Negeri 1 Lhokseumawe are the final test results through the implementation of learning models using the group investigation learning model through domino mathematics media and by using conventional learning models on the material of rank numbers and root forms. The domino mathematics media used in learning can be seen in Figure 2.

By the previously defined data processing method, the data will be processed based on the criteria set.

\subsection{Analyzing of Research Results Data}

The results of the statistical calculation of preliminary test data from the results of the study have been obtained. The average score calculation $(\bar{x})$ of the experiment class was 44.21 while the control class average $(\bar{x})$ was 42.79 . The calculation results also obtained the initial test variance value of the experiment class $=$ 33.57 and the standard deviation value of the initial test of the experiment class $=5.79$. While the initial test variance value of the control class $=19.57$ and the default deviation value of the control class $=4.42$.

\section{- Test Normality of Initial Test Data Distribution}

The data distribution normality test aims to find out whether each of the groups in the research came from a normally distributed population or not. To test the normality data in this study used the Kolmogorov-Smirnov test with the formulation of the test hypothesis as follows:

$\mathrm{H}_{0}$ : Samples come from normally distributed populations

$\mathrm{H}_{1}$ : Samples came from abnormally undistributed populations

Using the level of significance $a=0.05$ then the test criteria are:

Accept $\mathrm{H}_{0}$ if sig value. $\geq \alpha$

Reject $\mathrm{H}_{0}$ if sig value. < a, (Uyanto, 2009)

Results from the Kolmogorov-Smirnov test normality analysis for experiment grade pretest data and control classes are presented in the following Table 2.

Table 2. Test normality of pretest data

\begin{tabular}{cccc}
\hline & \multicolumn{3}{c}{ Kolmogorov-Smirnov $^{\mathrm{a}}$} \\
\cline { 2 - 4 } & Statistic & $\mathrm{df}$ & Sig. \\
\hline Pre-test_Ex &, 128 & 14 &, $200^{*}$ \\
\hline Pre-test_Con &, 162 & 14 &, $200^{*}$ \\
\hline
\end{tabular}

Based on table 2 above it appears that the pretest scores of the experiment class students and the control class have sig scores. greater than $\mathrm{a}=0.05$ i.e. 0.2 . This means $\mathrm{HO}$ is accepted in other words experiment class pretest data and control classes come from normally distributed populations. Once it is known that the initial test data spread of the experiment class and the normally distributed control class, it is continued with the initial variance homogeneity test.

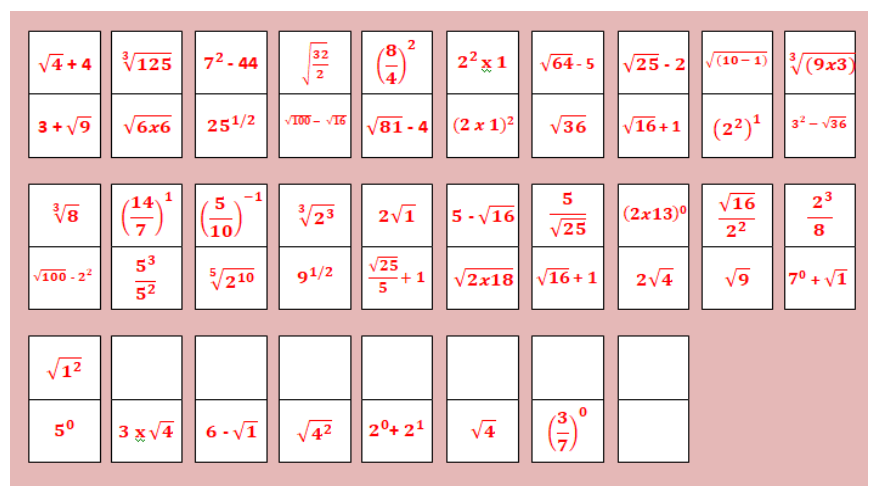

Figure 2. Mathematical domino media on the rank number and root form materials.

\section{- The Initial Variance Homogeneity Test}

Homogeneity testing is performed to test the homogeneity of variance data to be analyzed between the experiment class and the control class. According to (Sundayana, 2010) the hypothetical pairs to be tested inhomogeneity testing are as 
follows:

$H_{o}: \sigma_{1}^{2}=\sigma_{2}^{2}$ (both homogeneous variances)

$H_{1}: \sigma_{1}^{2} \neq \sigma_{2}^{2}$ (both variances are not homogeneous)

Using the level of significance $a=0.05$ then the test criteria are: Accept $\mathrm{H}_{0}$ if sig value. $\geq \alpha$

Reject $\mathrm{H}_{\mathrm{o}}$ if sig value. < a, (Uyanto, 2009).

Results from the variance homogeneity analysis of the Levene Statistic Test for experiment class pretest data and control classes are presented in the following Table 3.

Table 3. Variances homogeneity of pretest

\begin{tabular}{cccc}
\hline Levene Statistic & df1 & df2 & Sig. \\
\hline 1,146 & 1 & 26 &, 294 \\
\hline
\end{tabular}

Based on table 3 above it appears that the sig value. The pretest of both classes is larger than $a=0.05$ which is 0.294 . This means $\mathrm{H}_{0}$ is accepted in other words the pretest of both classes has a homogeneous variance.

\section{- Test the Normality of Post-test Data Distribution}

The data distribution normality test aims to find out whether the data that is the post-test of each group in this study comes from a normally distributed population or not. The author used the Kolmogorov-Smirnov test.

Table 4. Post-test Data Normality Test

\begin{tabular}{lccc}
\hline & \multicolumn{3}{c}{ Kolmogorov-Smirnova } \\
\cline { 2 - 4 } & Statistic & df & Sig. \\
\hline Post-test_Ex &, 197 & 14 &, 146 \\
\hline Post-test_Con &, 165 & 14 &, $200^{*}$ \\
\hline
\end{tabular}

Based on table 4 above it appears that the post-test scores of experimental graders and control classes have sig scores. greater than $a=0.05$ which is 0.146 for the experiment class and 0.200 for the control class. This means $\mathrm{HO}$ is accepted in other words the posttest data of the experiment class and the control class comes from a normally distributed population. Once is known the distribution of the post-test data of the experiment class and the normally distributed control class, then proceed with the homogeneity test variance of the post-test

\section{- Variance Homogeneity of post-test}

Homogeneity testing is performed to test the homogeneity of the post-test data variance to be analyzed between the experiment class and the control class. Results from the variance homogeneity analysis of the Levene Statistic Test for the posttest data of the experiment class and control class are presented in Table 5.

Table 5. Variance homogeneity of post-test

\begin{tabular}{cccc}
\hline Levene Statistic & df1 & df2 & Sig. \\
\hline 1,390 & 1 & 26 &, 249 \\
\hline
\end{tabular}

Based on table 5 above it is noticeable that the sig value. the post-test of both classes is greater than $\mathrm{a}=0.05$ which is 0.249 . This means $\mathrm{H}_{0}$ is accepted in other words post-test both classes have homogeneous variance.

\section{- Postest Data Hypothesis Testing}

Previous test results showed that the posttest data of the experiment class and the normally distributed control class, as well as the variance of the two classes, were also homogeneous so that the statistical test to be used to test the average difference of the two samples was the parametric test that is the t-test. Concisely analyze the results of the posttest average difference test presented in the following Table 6 .

Table 6. Post-test Data Hypothesis Test

\begin{tabular}{clccc}
\hline & & \multicolumn{3}{c}{ T-Test For Equality of Means } \\
\cline { 3 - 5 } & & $\mathrm{t}$ & $\mathrm{df}$ & Sig. (2-tailed) \\
\hline \multirow{2}{*}{$\begin{array}{l}\text { Value } \\
\text { Postest }\end{array}$} & $\begin{array}{l}\text { Equal variances } \\
\text { assumed }\end{array}$ & 3,624 & 26 &, 001 \\
\cline { 2 - 5 } & $\begin{array}{l}\text { Equal variances not } \\
\text { assumed }\end{array}$ & 3,624 & 25,645 &, 001 \\
\hline
\end{tabular}

Table 6 indicates that the value of the sig. (2-tailed) posttest data is 0.001 which means less than $a=0.05$. Thus $\mathrm{HO}$ was rejected at a significant level $\mathrm{a}=0.05$. It can be concluded that the results of student learning through the implementation of a group investigation learning model through mathematical domino media better than the implementation of a conventional learning model on the rank number and root form materials in grade IX of SMP Negeri 1 Lhokseumawe. This is by previous research (Haridi, 2018) which concluded that there was an improvement in the results of learning mathematics through group investigative learning models and previous research (Lestari et al., 2019) which concluded that the implementation of group investigation learning models can improve the critical thinking skills of class XI students in circle materials.

As well as previous research (Rifa'i \& Sartika, 2018) which concluded that the results of mathematical learning of students who obtained group investigative learning were better than those who obtained conventional learning models. This is in agreement with the resulting study of the (Imam Kusmaryono, Hardi Suyitno, 2018) that said "mathematics learning with group investigation had succeeded in transforming negative disposition into (positive) productive disposition and to improve the productive disposition toward mathematics", and according to the result of (Sadikin Fahinu, 2016) research shows the application of the group investigation learning model more influential than the application of the conventional learning model to critical thinking ability mathematics students.

\section{CONCLUSION}

Based on the results of the analysis of research data, it can be concluded that: the results of student learning through the implementation of a group investigation learning model through mathematical domino media better than the implementation of a conventional learning model on the rank number and root form materials in grade IX of SMP Negeri 1 Lhokseumawe.

\section{ACKNOWLEDGEMENTS}

The authors would like to thank the teachers for their support especially Miss Heny and Miss Aflinar and students of SMPN 1 Lhokseumawe for their participation in this study. 


\section{REFERENCES}

Ahsanah, F. (2015). “Group Investigation": A Cooperative Learning Method for the 10 Th Grade Students in Speaking the GI Method. TELL Journal, 3(1), 57-69.

Alzahrani, K. S. (2017). Metacognition and Cooperative Learning in the Mathematics Classroom. International Electronic Journal of Mathematics Education, 12(3), 475-491.

Anggraini, L., Siroj, R. A., \& Ilma, R. (2010). Penerapan Model Pembelajaran Investigasi Kelompok Untuk Meningkatkan Kemampuan Pemecahan Masalah Matematika Siswa Kelas Viii-4 Smp Negeri 27 Palembang. Jurnal Pendidikan Matematika, 4(1). https:// doi.org/10.22342/jpm.4.1.309.

Arinda, Y., Wilujeng, I., \& Kuswanto, H. (2019). The Application Group Investigation (GI) Learning Model assisted Phet to Facilitate Student Scientific Work Skills. International Journal of Educational Research Review, 4(2), 254-261. https://doi.org/10.24331/ijere.518069

Dwi Indarti, M., \& Pramudya. (2017). Group investigation with scientific approach in mathematics learning. CMSE, 1-5.

Fonna, M., \& Mursalin, M. (2019). Using of wingeom software in geometry learning to improving the of mathematical representation ability. Malikussaleh Journal of Mathematics Learning (MJML), 1(2), 40-43.

Haridi. (2018). Penerapan Pembelajaran Group Investigation Untuk Meningkatkan Hasil Belajar Matematika Siswa Kelas X Ipa 1 Man 2 Banyuwangi. AXIOM: Jurnal Pendidikan Dan Matematika, $7(2)$.

https://doi.org/10.30821/axiom.v7i2.2891

Hasibuan, A. M., Saragih, S., \& Amry, Z. (2019). Development of Learning Materials Based on Realistic Mathematics Education to Improve Problem Solving Ability and Student Learning Independence. International Electronic Journal of Mathematics Education, 14(1), 243-252.

Hendriana, H. (2017). Teachers ' hard and soft skills in innovative teaching of mathematics. WIETE, 15(2), 145-150.

Herawati, E. (2017). Upaya Meningkatkan Motivasi dan Hasil Belajar Siswa Menggunakan Media Pembelajaran Kartu Domino Matematika Pada Materi Pangkat Tak Sebenarnya dan Bentuk Akar Kelas IX SMP Negeri Unggulan Sindang Kabupaten Indramayu. JNPM (Jurnal Nasional Pendidikan Matematika), 1(1), 66-87.

Imam Kusmaryono, Hardi Suyitno, D. and N. D. (2018). Group Investigation Based Learning Improves Students' Productive Disposition and Mathematical Power. International Journal of Education, Learning and Development, 6(5), 26-37.

Lestari, E., Cahyono, H., \& Awaluddin, A. (2019). Penerapan model pembelajaran group investigation pada materi lingkaran untuk meningkatkan kemampuan berpikir kritis. Jurnal Math Educator Nusantara: Wahana Publikasi Karya Tulis Ilmiah Di Bidang Pendidikan Matematika, 5(2), 124-139. https://doi.org/10.29407/jmen.v5i2.12814

Maulidawati, M., Muhammad, I., Rohantizani, R., \& Mursalin, M. (2020). The Implementation of Make a Match Type Cooperative Learning Model to Improve the Mathematical Connection Ability. International Journal for Educational and Vocational Studies, 2(11).

Mendes, I. A. (2019). Active Methodologies as Investigative Practices in the Mathematics Teaching. International Electronic Journal of Mathematics Education, 14(3), 501-512.

Muhammad, M. (2018). The Effect of Group Investigation ( GI ) Cooperative Learning Type on Mathematical Problem and
Self-Confidence of the Students in SMP Negeri 2 Rembang. ASSEHR, 267, 91-94.

Nugraha, A. G., \& Rafidiyah, D. (2019). Training of Using Domino Card Game to Teach Fraction for Mathematics Teachers at Junior High Schools in Banjar Regency. An International Journal of Community Development, 1(3), 67-70.

Paroqi, L. L., Mursalin, M., \& Marhami, M. (2020). The Implementation of Realistic Mathematics Education Approach to Improve Students' Mathematical Communication Ability in Statistics Course. International Journal for Educational and Vocational Studies, 2(10).

Putriani, D., \& Rahayu, C. (2018). The effect of discovery learning model using sunflowers in circles on mathematics learning outcomes. International Journal of Trends in Mathematics Education Research, 1(1), 22-25.

Ridhollah, M., Muliana, M., \& Mursalin, M. (2021). The Influence of Cooperative Integrated Reading and Composition Model on Completing Abilities of Story Questions. Malikussaleh Social and Political Reviews, 2(1), 33-42.

Rifa'i, R., \& Sartika, N. S. (2018). Penerapan Pembelajaran Investigasi Kelompok terhadap Hasil Belajar Matematis Siswa Sekolah Menengah Pertama. Jurnal Analisa, 4(1), 43-50. https:// doi.org/10.15575/ja.v4i1.1960

Rusman. (2010). Mengembangkan Profesionalisme Guru. Rajawali Pers.

Sadikin Fahinu, R. and K. (2016). Effect of Application of Learning Model Group Investigation on Critical Thinking Ability of Mathematical High School Students. 208-212.

Sarah, K., Mursalin, M., Muliana, M., Nuraina, N., \& Rohantizani, R. (2021). The Influence of the Inside Outside Circle Cooperative Learning Model on Students' Mathematical Communication Ability. International Journal for Educational and Vocational Studies, 3(3), 177-185.

Sheromova, T. S., Khuziakhmetov, A. N., Kazinets, V. A., Sizova, Z. M., Buslaev, S. I., \& Borodianskaia, E. A. (2020). Learning Styles and Development of Cognitive Skills in Mathematics Learning. EURASIA Journal of Mathematics, Science and Technology Education, 16(11), 1-13.

Samsuriadi, S., \& Imron, M. A. (2019). The Effect of Think Pair Share (TPS) Learning Model with Problem Solving Approach on the Student's Math Communication in MA DA Jarowaru. Malikussaleh Journal of Mathematics Learning (MJML), 2(1), 9-12.

Siagian, M. V, Saragih, S., \& Sinaga, B. (2019). Development of Learning Materials Oriented on Problem-Based Learning Model to Improve Students ' Mathematical Problem Solving Ability and Metacognition Ability. International Electronic Journal of Mathematics Education, 14(2), 331-340.

Sofroniou, A., \& Poutos, K. (2016). Investigating the Effectiveness of Group Work in Mathematics. MDPI, 1-15. https://doi.org/10.3390/educsci6030030

Sri Adi Widodo, W. (2018). Selection of Learning Media Mathematics for Junior School Students. TOJET, 17(1), 154-160.

Sumarmi. (2012). Model-Model Pembelajaran Geografi. Aditya Media.

Sundayana, R. (2010). Statistika Penelitian Pendidikan. STKIP Garut Press.

Suprihatiningrum, J. (2013). Strategi Pembelajaran Teori dan Aplikasi. Ar-Ruzz Media.

Untoro, B. (2016). The Effect of Group Investigation and Learning Style on Students' Writing of Analytical Exposition. IJEE, 3(1), 29-45. https:// doi.org/10.15408/ijee.v3i1.3445

Usmadi, U., Hasanah, H., \& Ergusni, E. (2020). The impact of the implementation three-step Interview cooperative learning 
model in mathematics learning toward the learners' activities and outcomes. Malikussaleh Journal of Mathematics Learning (MJML), 3(1), 8-12.

Uyanto, S. (2009). Pedoman Analisis Data dengan SPSS. Graha Ilmu.

Wulandari, P., Mujib, M., \& Putra, F. G. (2016). Pengaruh Model Pembelajaran Investigasi Kelompok berbantuan Perangkat Lunak Maple terhadap Kemampuan Pemecahan Masalah Matematis. Al-Jabar: Jurnal Pendidikan Matematika, 7(1), 101-106.

http://ejournal.radenintan.ac.id/index.php/al-jabar/article/ view/134/124

Yarmasi, Y., Fonna, M., \& Mursalin, M. (2020). The Influence of Cooperative Learning Model Type Team Assisted Individualized of Interactive Media Assistance to Students' Mathematical Communication Ability. International Journal for Educational and Vocational Studies, 2(9). 